\title{
Entrevista com Paulo Fonteles Filho
}

Cristina Buarque de Hollanda

\author{
Paulo Fonteles Filho \\ Foi vereador de Belém do Pará (2001-2008) pelo PC do B), membro da \\ Comissão da Verdade do Pará e presidente do Instituto Paulo Fonteles, \\ dedicado ao legado e à continuação da ação política de seu pai, ex- \\ deputado estadual do Pará assassinado em retaliação a suas denúncias \\ de irregularidades fundiárias na região.

\section{Cristina Buarque de Hollanda} \\ Professora do Instituto de Estudos Sociais e Políticos da Universidade \\ do Estado do Rio de Janeiro. \\ E-mail: cristinabuarque@gmail.com \\ ORCID: https://orcid.org/0000-0002-1600-4044
}

[A conversa com Paulo começou informal, sem gravador e em frente ao computador, de onde ele sacava documentos e documentários. Não quis interrompê-lo para um começo formal que poderia ameaçar a espontaneidade. Aos poucos cuidei de estruturar a entrevista em torno da pauta dos mortos e desaparecidos políticos, o principal fio condutor da sua militância política]

\section{PAULO FONTELES FILHO:}

Eu sou relator da Comissão [da Verdade do Pará]. Eu fiquei com essa tarefa e responsabilidade de fazer um relatório parcial das suas atividades. $\mathrm{E}$ a gente deve apresentar o relatório agora, 5 ou 6 de maio [de 2017], exatamente no período em que nós queremos criar a Comissão da Verdade em Marabá.

\section{CRISTINA BUARQUE DE HOLLANDA:}

Essa Comissão de Marabá surge por estímulo de vocês [da CV Pará]?

\section{PAULO FONTELES FILHO:}

Sim, nós estamos estimulando e existem movimentos sociais que estão trabalhando essa perspectiva. Por exemplo, aqui a partir de 2005, a gente criou a associação de torturados na guerrilha do Araguaia, que é a reunião desses camponeses que foram atingidos pela repressão política. E foi algo muito interessante porque em certa medida reforçou a luta reparatória desses camponeses. Não apenas a luta reparatória, porque esse movimento como também a nossa própria ação - atua com base em cinco marcos fundamentais: primeiro, a verdade. Nos interessa a verdade. Em segundo lugar, a questão dos desaparecidos políticos. O Pará reúne grande parte dos desaparecidos políticos do país por conta da guerrilha do Araguaia. O terceiro aspecto é o da reparação, seja psíquica, seja econômica. Um quarto aspecto é a luta pela justiça. Nós achamos que aqueles que atuaram como lobos na repressão devem ser punidos. Nós precisamos revisar essa lei da Anistia de 1979. E um quinto aspecto é o aspecto da educação pela memória. Esse debate tem que ir para as escolas, para as universidades. Deve fazer parte, digamos, da vida dos brasileiros. Se nós tivéssemos isso de forma muito mais forte, talvez a gente não assistisse o Brasil ter a 
democracia subjugada como está nesse momento. Com esse golpe que deram na democracia do país [referência ao impeachment de Dilma Rousseff, em agosto de 2016], fazendo com que essa turma de gângsteres assumisse a direção do país. Esses cinco aspectos são fundamentais para essa atuação. Essa atuação tem esse formato da Associação de Torturados do Araguaia, mas também a Comissão da Verdade, a luta para localizar os desaparecidos políticos, [pois] isso aqui é uma luta muito presente no estado do Pará e na atuação que a gente tem. Por outro lado, um incentivo para a criação de comissões de verdade. Marabá tem que ter uma comissão da verdade. Existem ainda as experiências nas universidades. Tem aqui a experiência da [Comissão da Verdade da] UFPA [Universidade Federal do Pará], que é muito interessante. Tem uma outra experiência interessante [de comissão da verdade] que é na UNIFESP, a Universidade Federal do Sul e Sudeste do Pará. A gente tem tido uma parceria muito interessante com a própria universidade, no sentido inclusive de reunir materiais para a formação de um acervo da própria universidade, visto que é uma universidade nova. A UNIFESP foi a última das universidades criadas pela Dilma. Tem lá um grupo que também trabalha nesta perspectiva e que é em certa medida a própria Comissão da Verdade da UNIFESP. Fez algumas ações interessantes conosco, como a ação ligada ao Museu da Guerrilha do Araguaia, de São Geraldo. Não sei se você conhece essa história.

\section{CRISTINA BUARQUE DE HOLLANDA:}

Não conheço. Que história é essa?

\section{PAULO FONTELES FILHO:}

Nós fizemos uma diligência ao Museu da Guerrilha do Araguaia, em São Geraldo, e descobrimos que o dono do museu era um cara da repressão. A gente fez inclusive um filmezinho sobre isso. Tem muita coisa [a ser debatida e tornada pública]. Aqui [na Comissão da Verdade do Pará] nós temos enfrentado problemas no nível da falta de apoio.

\section{CRISTINA BUARQUE DE HOLLANDA:}

Paulo, antes de entrarmos por aí, poderíamos voltar um pouco no tempo? Você poderia me contar a história da Comissão desde o começo? E também, junto com isso, gostaria de ouvir sobre a história do seu envolvimento com a Comissão. Eu li sobre a história de seu pai' e imagino que os assuntos com que a Comissão lida tenham sido sempre muito presentes na sua vida.

\section{PAULO FONTELES FILHO:}

Minha mãe também. Minha mãe teve os dois filhos na prisão. Eu nasci e fui gerado na prisão. É uma história muito doida.

\section{CRISTINA BUARQUE DE HOLLANDA:}

Eu posso intuir os motivos que te levaram a se aproximar da Comissão, mas gostaria de te ouvir a respeito.

\section{PAULO FONTELES FILHO:}

Sim. [A minha trajetória] tem tudo a ver [com a minha participação na Comissão]. Na verdade, a minha ligação com essa questão do Araguaia e com a repressão é o fato de [como se deu] o meu nascimento. Eu nasci nos cárceres da ditadura militar, sob a frase de que "filho desta raça não deve nascer". Minha mãe foi presa, grávida de cinco meses, em Brasília. Meus pais eram estudantes da Universidade de Brasília. Meu pai, estudante de Direito e minha mãe, de Ciências Sociais. Na hora da prisão, o delegado da Polícia Federal 
disse que filho de comunista não devia nascer. Então perceberam que ela estava grávida, né? E passamos por todo o inferno da tortura. Eu me incluo porque eu estava ali. Uma história muito dura. O que me faz falar sobre isso? A única forma que a gente tem de resolver essa questão é podendo falar sobre essa situação. E desde muito cedo. Eu sou de uma família de comunistas. Meus pais ao saírem da prisão não renunciaram à luta, muito ao contrário, afirmaram essa luta. $\mathrm{E}$ a atitude deles foi muito corajosa porque eles não vacilaram em denunciar a tortura, seja em Brasília, nas primeiras sessões, nos Superiores Tribunais Militares, como aqui em Belém também, no final da década de setenta quando eles denunciaram no jornal Resistência que foram torturados. Na Barão de Mesquita, dentro do Ministério do Exército. Meus pais foram torturados dentro do Ministério, nas dependências do Ministério do Exército. Eu tenho a convicção, Cristina, de que eu só estou aqui porque a minha mãe enfrentou a ditadura. $\mathrm{E}$ a única forma que ela poderia [ter de] enfrentar a ditadura era assegurando o meu nascimento. E isso de fato aconteceu. Quando eu nasci minha mãe tinha trinta e sete quilos, foi cortada de uma ponta à outra e não disse um ai. $E$ isso revela a firmeza, a bravura, a capacidade de resistência também, porque a tortura sobre as mulheres é sempre muito mais traumática do que sobre os homens por tudo que eles podem fazer. Por tudo que os violentos podem fazer. Isso também nos conferiu essa firmeza, tanto a mim quanto aos meus irmãos, no geral. Porque foram eles que nos deram. Meu pai depois foi assassinado [em 11 de junho de 1987]. Quando nós tínhamos quinze anos de idade, ele foi morto porque se tornou advogado de trabalhadores rurais no sul do Pará, exatamente nessa região onde havia acontecido a guerrilha do Araguaia. Foi deputado estadual [1984-1987]. Era um dirigente do Partido Comunista do Brasil e foi morto por pistoleiros. Esses episódios na vida fizeram com que a gente tivesse a clareza de que a gente tem que enfrentar. Não podemos nos quedar diante dos poderosos, dos violentos, daqueles que acham que matando, torturando podem submeter a luta do povo ao inferno. $E$ desde muito cedo, quando meu pai foi morto, - e eu sou o filho mais velho - eu decidi entrar no Partido Comunista. Uma das coisas que me salvou, digamos assim, a capacidade de enfrentamento, ter lucidez, foi a própria militância política. Eu atribuo à militância política esse processo como um todo. Mas desde a nossa infância, o tema da guerrilha está muito presente. O tema da tortura está muito presente. Uma das primeiras informações que eu tive sobre mim mesmo foi o fato de ter nascido na prisão e ser filho de comunistas. O que eu faço agora não é estranho nem contraditório; está harmonizado com a minha infância. Nós moramos no sul do Pará durante algum tempo. E a presença da guerrilha e da resistência, da luta dos posseiros, desse enfrentamento ao latifúndio, diante da penetração econômica da Amazônia sempre foi muito clara para nós. Sempre foi muito viva para nós. E meus pais sempre foram pessoas muito abertas nesse sentido. Sempre nos colocaram a coisa de forma muito clara. Então, a militância que eu travo no âmbito da memória e da verdade está nessa perspectiva. É claro que é uma perspectiva histórica, é uma perspectiva de que nós não queremos revanche, queremos justiça. $E$ o meu envolvimento com isso tem [a ver com] esse processo da infância, mas já na década de 90 eu passo a militar nessa área. Eu fui morar no Rio, estudei na UER] [Universidade do Estado do Rio de Janeiro]. Passei em 1991 para a universidade daqui, mas me transferi para o Rio de Janeiro. E no Rio tive muita convivência com Elza Monnerat. E como militante do partido comecei a trabalhar com a Elza no recolhimento das coisas do Araguaia e nesse processo todo. E a partir de 1996 eu começo a viajar para a região já nesse esforço no sentido da localização de desaparecidos políticos. Tu sabes que um impulso importante que a gente teve na década de noventa foi aquela matéria d'O Globo, na segunda quinzena de maio de 1996 , quando $O$ Globo havia conseguido um arquivo de um coronel reformado, acho que do Exército, e que fez dez matérias seguidas. $E$ isso acabou gerando uma onda de retomada das buscas lá no Araguaia. Digo para ti que meu pai foi um dos coordenadores da primeira caravana da 
guerrilha do Araguaia. Essa foto aqui [aponta para a parede], Cristina, é do debate que ele fez no Rio, na ABI, porque ele coordenou a primeira caravana em 1980 como advogado indicado pela Ordem dos Advogados do Brasil (OAB). A caravana foi uma pedra de toque na luta pela verdade e pela memória no Brasil. Ela comprovou uma série de coisas: primeiro que houve a guerrilha, segundo que de fato os guerrilheiros foram mortos sob custódia do Exército e que os camponeses foram ferozmente atingidos, foram mortos e seus corpos ficaram desaparecidos.

\section{CRISTINA BUARQUE DE HOLLANDA:}

E seu pai foi assassinado alguns anos depois, certo?

\section{PAULO FONTELES FILHO:}

Em 87. Meu pai depois foi deputado [estadual pelo estado do Pará]. Essa atividade aqui foi em 81 porque a caravana foi no final de 80 , em outubro e novembro. Nessa viagem que eu faço ao Araguaia na década de 90 nós encontramos quatro fotografias de desparecidos políticos. Esse aqui é o Antônio Pádua Costa. Isso aqui são os caras presentes. E é uma imagem, Cristina, da terceira campanha [referindo-se à fotografia da Guerrilha do Araguaia que me mostra na parede do escritório]. Estão todos barbudos, sem a roupa de militar. $\mathrm{Na}$ década de 90 eu fui passar dez dias na região acompanhando essa missão do Ministério da Justiça com familiares [de mortos e desaparecidos] e acabei ficando um ano. Tranquei a universidade e saí da região com uma escoliose e doze quilos mais magro. Eu sempre ouvia histórias do Araguaia. Minhas histórias de ninar na infância eram as histórias da guerrilha.

\section{CRISTINA BUARQUE DE HOLLANDA:}

Em que área é a sua formação universitária?

\section{PAULO FONTELES FILHO:}

Eu fiz Filosofia. E a partir desse momento eu passo a participar desse processo todo: dessas buscas, desse esforço no sentido de a gente compor os primeiros mapas sobre o problema da guerrilha do Araguaia, [da busca d'] os locais onde o pessoal foi sepultado. Então, desde essa época, Cristina, eu tenho participação e envolvimento. Estimulei a organização de camponeses, no sentido da reparação e no sentido da localização. O papel dos camponeses nesse processo todo tem sido muito importante. Desde o final da década de setenta até hoje, [eles têm o] papel de relatar o que foi a guerrilha e os camponeses ainda são invisibilizados como são os indígenas. Os indígenas muito mais, porque eles aparecem com mais força apenas nesse ambiente da comissão da verdade. Foram invisibilizados.

A partir de 2009 eu passo a compor o grupo de trabalho Tocantins ${ }^{\text {ii }}$ e depois o grupo de trabalho Araguaiaiii, no sentido da localização de desaparecidos políticos. A partir desses dois grupos de trabalho nos foi permitido construir essa perspectiva da Comissão da Verdade no Pará. Participar desse processo todo foi muito difícil no início, porque no curso desses anos todos, Cristina, entre 2009 e 2010, nós não encontramos coisa alguma na região. Nada. Imagina o que é andar cinquenta mil quilômetros e não encontrar absolutamente nada?! Existe uma importante virada no processo todo no momento em que os ex-soldados entram na história. A partir disso e com o aspecto também de que o próprio Exército perdeu força no curso desse trabalho, é que nós conseguimos encontrar os primeiros [indícios]. Entre 2011 e hoje - o trabalho está suspenso há um ano e meio por conta do golpe - já foram encontradas 21 ossadas. A luta pela reparação dos camponeses, que também começa em 2009, quando os primeiros camponeses são anistiados no Paráiv, no período do Tarso Genro, a luta pela localização, e também a experiência da Comissão Nacional, criaram as condições políticas para a gente discutir [o problema]. Foram os três aspectos que nos permitiram criar 
a Comissão da Verdade no Pará. Nós criamos um comitê paraense pela verdade, memória e justiça, em 2012, e fomos lutando no sentido da criação da comissão. E nós não criamos uma comissão por um decreto do governador, não. Nós criamos uma lei. Existe uma lei [estadual] que trata do problema da comissão. Inclusive aqui nesse documento tem a lei da Assembleia Legislativa do Estado do Pará. Eles só não acabaram com a gente, Cristina, porque nós temos uma lei! E na lei diz o seguinte: "a comissão da verdade estará extinta só após a entrega do relatório final." Ponto. (Risos)

\section{CRISTINA BUARQUE DE HOLLANDA:}

E como foi o processo político para a criação dessa lei?

\section{PAULO FONTELES FILHO:}

Foi grande e intenso.

\section{CRISTINA BUARQUE DE HOLLANDA:}

Entre as comissões estaduais, vocês compuseram uma das últimas [comissões] a serem criadas. Eu imagino que tenha sido um processo difícil.

\section{PAULO FONTELES FILHO:}

Foi uma luta política longa, que dialogava com a consciência social e democrática, porque o Pará não é qualquer estado nesse contexto. O Pará é um estado que foi muito atingido. A Amazônia como um todo, [embora] ainda invisibilizada e pouco conhecida. O relatório da CNV nos dá boas indicações. Uma delas é do genocídio indígena. A comissão indica que mais de nove mil pessoas foram mortas na Amazônia. Isso cala muito fundo. E ainda sobre os camponeses. Essa matança e esse modus operandi que não se encerrou na Amazônia paraense. Foi uma luta longa. Cercamos a Assembleia, conversamos com deputados, fizemos reuniões, mostras de cinema, a gente fez muita atividade. E esse próprio relatório explica esse esforço que nós realizamos. E nós conseguimos de fato. Com toda enrolação dos tucanos aqui. Por exemplo, nós criamos o comitê em março de 2012 e a comissão só foi instalada em setembro de 2014! Foram mais de dois anos de luta. O fato de participar desses grupos de trabalho [do Tocantins e do Araguaia] nos permitiu fazer muita agitação, no sentido de escrever artigos sobre isso, de problematizar a busca dos corpos e outras coisas. Fomos muito criticados, também, porque uma parcela desse movimento de direitos humanos repudiou a participação nesses grupos de trabalho junto com o Exército. Mas nós fizemos uma leitura clara, que era melhor estar ali dando e levando canelada do que ficar em Belém, São Paulo e Brasília e Rio de Janeiro fazendo guerra pela Internet. Vamos para o meio dos caras, para encontrar essa turma! Não dá para deixar nas mãos dos militares essa história. A militância política, o movimento de direitos humanos, o Partido Comunista, têm que fazer o enfrentamento. Foi o que nós fizemos, em certa medida. Foi uma boa luta, Cristina. Foi uma luta muito interessante, valeu à pena e agora temos pela frente o esforço de terminar o trabalho da Comissão.

\section{CRISTINA BUARQUE DE HOLLANDA:}

E como anda o trabalho da Comissão, Paulo?

\section{PAULO FONTELES FILHO:}

No final do ano passado [2016], o governo do estado [de Simão Jatene, do PSDB] demitiu todos os técnicos da Comissão, menos os comissionados. Eles só não acabam com a gente porque a lei não permite. A lei diz que a Comissão só pode ser extinta com a entrega do relatório. Nós vamos ter uma reunião [com os membros] da Comissão em breve. 


\section{CRISTINA BUARQUE DE HOLLANDA:}

Onde é a sede da Comissão?

\section{PAULO FONTELES FILHO:}

Não tem sede! Absolutamente nada! A sede da Comissão tem sido ou no escritório do Egídio [Machado Sales Filho], que foi presidente da Comissão. A gente inclusive está discutindo a presidência. Como também o Instituto [Paulo Fonteles] [tem servido de sede].

\section{CRISTINA BUARQUE DE HOLLANDA:}

A lei [de criação da Comissão] foi proposta pelo governo?

\section{PAULO FONTELES FILHO:}

Sim, foi proposta pelo governo. Houve deputados que fizeram projetos, mas eram inconstitucionais porque só o governo pode apresentar. A gente teve apoio no Parlamento, de deputados como o Edmilson [Rodrigues, PSOL] e Carlos Bordalo [PT], que foram muito sensíveis [à questão]. O Bordalo é membro da Comissão da Verdade do Pará. A pessoa que deve assumir a presidência dos trabalhos é ele. Nós já entrevistamos mais de quinhentas pessoas.

\section{CRISTINA BUARQUE DE HOLLANDA:}

Eu vi que vocês fizeram muitas oitivas com comunidades indígenas. Você poderia comentar como foi essa experiência? Ao que me consta, vocês foram a única comissão da verdade no país a recolher testemunhos de indígenas.

\section{PAULO FONTELES FILHO:}

Foi muito interessante. Primeiro porque a gente já tinha um trabalho com um povo, que são os Aikewoara. Trabalhamos com essa etnia porque estava no meio do contexto da guerrilha do Araguaia. Também porque a vida e as atividades nos empurravam para uma relação maior [com eles]. Os Aikewoara junto com os Xavante foram os únicos povos indígenas que fizeram suas comissões de verdade.

\section{CRISTINA BUARQUE DE HOLLANDA:}

Eles fizeram suas próprias comissões da verdade?

\section{PAULO FONTELES FILHO:}

Sim, fizeram.

\section{CRISTINA BUARQUE DE HOLLANDA:}

Quando? Depois da Comissão Nacional [da Verdade (CNV), encerrada em dezembro de 2014]?

\section{PAULO FONTELES FILHO:}

Não, no âmbito da própria Comissão Nacional da Verdade. Inclusive, foi a Maria Rita Khel [uma das comissionarias da CNV] quem esteve comigo na região e a gente enfrentou esse desafio de ouvir e de passar a ter uma comissão. Eles decidiram por ter uma comissão. [Você] consegue localizar esse material que eles produziram online. E nós fomos um dos principais incentivadores dessa Comissão da Verdade. Eles fizeram um relatório e em seguida 14 deles foram anistiados. Não tem uma nação indígena que tenha mais membros anistiados que os Aikewara. Isso também nos permitiu uma relação de maior confiança com eles. Claro que eu já os conhecia. Desde [19]96 eu já tinha informações sobre eles, mas a 
partir de 2009, nesse trabalho do Araguaia, a gente foi mantendo relação. E aquela coisa de busca dos desaparecidos políticos. Nessa relação com eles a gente foi compreendendo a dinâmica e a cosmologia dos próprios indígenas. No início existia uma desconfiança grande, mas fomos superando isso e a gente pode dizer que a gente cumpriu com o que prometeu. E lutamos para que eles fossem reconhecidos e reparados.

\section{CRISTINA BUARQUE DE HOLLANDA:}

A reparação era uma demanda que vinha deles?

\section{PAULO FONTELES FILHO:}

Sim. Cristina, a realidade do Pará foi muito cruenta. Setenta por cento dos Parakanã desapareceram no período de construção da hidrelétrica de Tucuruí e de cinco remoções forçadas. Os Aikewoara, além de terem suas mulheres estupradas e seus homens colocados para serem guias das Forças Armadas, além de tudo isso, eles ficaram vivendo em confinamento, o que os fez perder algumas referências de tradição. Uma coisa que eles só vão começar a recuperar a partir de agora. Isso tem outros aspectos. Em torno de 25 indígenas estão na universidade. A UEPA [Universidade do Estado do Pará] tem um bom trabalho com os indígenas, tem um núcleo de estudos sobre o tema. Isso representa um ressurgimento dessa nação e isso é um milagre! À época da ditadura militar eles foram reduzidos a trinta a três [pessoas], a ponto de o adultério passar a ser socialmente aceito. Se eu era índio e não podia fazer filho numa índia, tinha que vir outro para fazer, porque o que mais importava era a manutenção, a sobrevivência da própria etnia. $E$ depois nós começamos a fazer um documentário, foram feitas várias matérias, também. A matéria do Ismael Machado, que foi premiada com o Líbero Badaró [Prêmio Líbero Badaró, atribuído ao Dossiê Curió, publicado no Diário do Pará] e o Vladimir Herzog [Prêmio Vladimir Herzog de Anistia e Direitos Humanos, atribuído à série Os Suruí e a Guerrilha do Araguaia] fala um pouco da história desse povo. Ele também é o autor desse livro [referência a Golpe, contragolpes e guerrilhas: o Pará e a ditadura militar, publicado em 2014 pela editora IAP]. É um recorte indígena muito pequeno para o tamanho da Amazônia. Mas é o limite do que foi possível para a gente fazer. Se nós tivéssemos condições, a gente teria dado importantes saltos. Por exemplo, os arquivos da FUNAI, lá em Marabá. Nós estamos quase pegando esse material para digitalizar esses arquivos. Uma parte do trabalho da Comissão é oral, com base nos depoimentos, mas fazemos também um trabalho comprobatório, uma parte também se fundamenta nos arquivos. A gente tem feito um esforço conjunto com a Universidade Federal do Sul do Pará (UNIFESSPA) para recolhermos esse material, para que a questão indígena no relatório final da Comissão Nacional da Verdade esteja bem situada. Naturalmente com as limitações que nós temos, que são imensas. Mas a realização da Comissão da Verdade é muito mais resultado da vontade e da consciência dos seus membros do que uma decisão governamental.

\section{CRISTINA BUARQUE DE HOLLANDA:}

Entendi. A despeito desses limites, quais são os alcances de vocês?

\section{PAULO FONTELES FILHO:}

Eu acho que o alcance é de fazer um bom retrato do que foi esse período no Pará, na Amazônia paraense. É retratar bem isso. Pensar, por exemplo, quem são as vítimas da perseguição política? Mas voltando à questão indígena: [uma situação que ocorria muito durante as atividades da Comissão], alguém dizia: "o pessoal está falando na língua deles." Deixem-nos falar. Não botamos nossas palavras lusíadas na boca deles! Teve um caso interessantíssimo: Mikoá seguramente foi a pessoa mais velha que fez depoimento em 
comissões de verdade. Esse índio tem cem anos de idade e foi fazer depoimento. $E$ fez isso na língua dele! A gente vai dizer que não?

\section{CRISTINA BUARQUE DE HOLLANDA:}

Vocês tinham tradutor?

\section{PAULO FONTELES FILHO:}

A gente tem os tradutores. A juventude indígena universitária é muito solidária. A gente conta com esse apoio e com essa relação de confiança, também. Mas isso quase foi um problema no início. E decidimos deixar as pessoas optarem por escolher falar na língua que preferissem e havia o tradutor para mediar se fosse necessário.

\section{CRISTINA BUARQUE DE HOLLANDA:}

E vocês têm essas traduções?

\section{PAULO FONTELES FILHO:}

A gente ainda está traduzindo este material. Tem uma parte já pronta, mas não está comigo. A pessoa que está responsável é a Célia Maracajá. A gente entrevistou mais de cem Aikewoara. Eu acabei participando da pesquisa de um documentário sobre os Aikewoara, sobre esse contexto deles e a ditadura.

\section{CRISTINA BUARQUE DE HOLLANDA:}

Quando estive no Amapá entrevistando os membros da Comissão da Verdade de lá, comentaram comigo sobre dificuldades na comunicação com os indígenas. Dificuldades que não tinham apenas a ver com o idioma, mas com o fato de que, ao serem instigados a falar sobre o passado, sobre a ditadura, os indígenas fariam isso em linguagem mítica. Produziam uma narrativa que não se ajustava bem aos propósitos da Comissão.

\section{PAULO FONTELES FILHO:}

Não, isso é uma certa fantasia, para mim. É claro que a cosmologia indígena é diferente da nossa. Claro que tem muito de mítico nessa cosmologia e a gente também tem que aprender a lidar com isso. Mas foi tranquilo. Sempre uma relação muito boa, uma relação que foi construída e que não é simples, porque é preciso ter muito respeito. Não pode vacilar com índio! Você se comprometeu na relação e se não cumprir com o prometido, você fragiliza e põe em risco a relação. Eles são muito receosos. Têm muita história de espoliação, de matança, particularmente no estado do Pará. Esses índios foram muito perseguidos, muito antes da guerrilha do Araguaia, na questão dos castanhais, havia um sujeito chamado Coriolano que era matador de índio. Reza a lenda que tinha um cão comedor das tripas dos índios. Essa turma foi muito acuada, viveu sob o medo e sob a violência. Quando você trata as pessoas com dignidade e com respeito, é o limite que tem que ser comprometido. Isso é muito importante.

\section{CRISTINA BUARQUE DE HOLLANDA:}

Além dessas Comissões indígenas a que você se referiu, vocês chegaram a estabelecer contato com outras comissões da verdade no país?

\section{PAULO FONTELES FILHO:}

A Comissão Nacional [CNV] foi a grande incentivadora do trabalho da gente. Primeiro porque, antes de criar a Comissão da Verdade, o Comitê Paraense realizou duas ou três grandes atividades com a Comissão Nacional. O Comitê puxando, organizando, indo, resolvendo, articulando. Uma delas foi uma grande audiência pública em Belém, uma 
audiência pública lá em Marabá, além da visita da Maria Rita Khel, da criação da Comissão da Verdade Aikewoara.

\section{CRISTINA BUARQUE DE HOLLANDA:}

E qual é a sua avaliação, Paulo, sobre o trabalho da Comissão Nacional?

\section{PAULO FONTELES FILHO:}

Olha, eu vejo algumas figuras reclamando das limitações da Comissão Nacional. Eu acho que limitação vai haver em qualquer lugar, né? Numa perspectiva de que a democracia no Brasil não foi consolidada. Quer dizer, essa transição democrática no Brasil não foi concluída porque, apesar de todo o esforço que tem sido feito, a gente ainda não tem todo o panorama dessa verdade. Segundo, porque ainda existem muitos desaparecidos políticos. Terceiro, porque nem todas as vítimas foram reparadas. Quarto, os caras estão impunes. Então, a transição democrática não se concluiu. Claro que, ao não se concluir, [esse processo de comissões de verdade] vai ter limitações. No geral, porém, o trabalho da comissão [CNV] foi muito importante para o país e a memória nacional. As suas recomendações precisam ser efetivadas. Vai ser uma luta nossa, inclusive, também. Passando as atividades da Comissão [do Pará], a luta vai ser para efetivar as recomendações. O estado paraense precisa de um espaço que trate de memória e verdade e não entenda que terminou o trabalho da comissão porque terminou a investigação sobre os crimes da ditadura. Muito pelo contrário. Até porque, Cristina, estão pipocando informações sobre desaparecidos políticos. Eu viajei para o sul do Pará há dez dias e recebi nesse período duas informações de ossadas. Vou te mostrar a carta que recebi com gente indicando locais onde estão desaparecidos políticos. No curso desses últimos dez anos, a gente foi enfrentando o medo e o silêncio, tirando os véus do medo. Muita gente tem medo. Teve o episódio do assassinato do Raimundo [trecho inaudível], em 2011. Quando a gente deu a virada para encontrar as ossadas, um [mateiro] que sempre foi ligadíssimo ao Curió, passou a colaborar conosco. Esse sujeito foi assassinado! A gente diz que foi o último assassinato da ditadura militar no Brasil.

\section{PAULO FONTELES FILHO:}

Cristina, eu vou te mostrar aqui a história do museu de São Geraldo do Araguaia [apontando para o computador]. Foi uma diligência que nós fizemos à região. Nesse processo todo eu já participei fazendo pesquisa para cinco ou seis documentários. Isso foi uma coisa que nós encontramos. Num primeiro momento, o cara [Eduardo Lemos] montou um museu de história natural da Amazônia. Quando acabou a ditadura, virou museu da guerrilha do Araguaia. Isso aqui foi feito pelo Exército, em São Geraldo do Araguaia. A Comissão da Verdade, em contato com a UNIFESP, mobilizou uma associação dos capturados da guerrilha para uma diligência a esse museu. O museu estava completamente abandonado, completamente sucateado, está em vias inclusive de desabar. Encontramos ali um crânio. Cristina, esse foi o local mais horroroso que eu entrei na minha vida. Parecia o purgatório. Se existir o purgatório, é esse espaço, quando nós encontramos. Tem ali grande parte do acervo comissionado, de aproximadamente seis mil itens. Tem muito material etnográfico, arqueológico, antropológico, mineralógico. Tem também documentos oficiais.

\section{CRISTINA BUARQUE DE HOLLANDA:}

Quer dizer, o museu estava abandonado e vocês entraram para tentar verificar o que havia ali, foi isso? 


\section{PAULO FONTELES FILHO:}

Nós sempre tivemos contato com esse Eduardo Lemos. Sempre tivemos relação com ele. Porque ele se passava por esse papel de bom moço, de pesquisador, o baiano que veio trabalhar em fazenda como técnico agrícola, que se interessou pela fauna e pela flora. $\mathrm{E} o$ cara montou, de fato, um museu. Com mais de seis mil itens. Material de zoobotânica, sobre [cultura material] indígena, uma mistura de vestígios de diferentes áreas. E nós nos relacionávamos com ele. Num certo momento, ele deve ter rompido com os caras da repressão. E deve ter se sentido ameaçado, e por essa relação conosco, nós acabamos incentivando que ele entrasse no programa de proteção às testemunhas. A informação que nós tínhamos é que ele tinha um sério conflito que nós não conseguíamos entender. $\mathrm{E} O$ conflito era com a verdade.

\section{CRISTINA BUARQUE DE HOLLANDA:}

Claro. Com o envolvimento dele próprio.

\section{PAULO FONTELES FILHO:}

Eu tenho todos esses documentos em casa para colocar no relatório. Em 73, esse Eduardo Lemos fez o seguinte: ele deu um curso na Marinha de 660 horas. É como se fosse uma pósgraduação, um mestrado ou um doutorado, uma coisa desse nível. E como nós descobrimos isso? O museu estava abandonado e nós fomos fazer uma visita. Eu sempre conheci aquela história toda e vi documentos da CPT [Comissão Pastoral da Terra] jogados no chão. Documentos da CPT jogados e eu pensei: "como que um material desses está jogado no chão, pegando chuva, pegando sol e umidade?!" Era o penúltimo dia de uma expedição do grupo de trabalho Araguaia e lá eu decidi que a Comissão da Verdade faria uma diligência também ali para ver o que encontraríamos. Nós tiramos cerca de duzentos e cinquenta quilos de papel.

\section{CRISTINA BUARQUE DE HOLLANDA:}

Que loucura!

\section{PAULO FONTELES FILHO:}

E aí tiramos e guardamos esse material e eu planejei voltar no mês seguinte para a gente ver o que havia lá de fato. Nós nos articulamos com a prefeitura de São Geraldo, que nos cedeu um espaço, operários e as condições para a gente recolher o material.

\section{CRISTINA BUARQUE DE HOLLANDA:}

E vocês precisaram de algum mandato judicial para isso?

\section{PAULO FONTELES FILHO:}

Não. Conversamos com a prefeitura sobre essa questão e eles nos designaram dois operários, um caminhão e um local para guardar esse material. Num dia recolhemos tudo e vinte dias depois eu voltei. No meio do material que recolhemos descobrimos que o cara era da repressão! Havia materiais do GETAT, que foi o Grupo Executivo de Terras do Araguaia e Tocantins, que foi um grupo que militarizou a política fundiária no final da década de setenta. O GETAT é de oitenta, num período de grande crescimento da luta dos camponeses. Para tu teres uma ideia, em 79, mais de 250 mil hectares de terra dessa região foram ocupados pelo movimento camponês. Foi uma luta dos posseiros pela posse das terras. $\mathrm{E}$ aí nós descobrimos esse material todo. Nele havia provas de vigilância dos indígenas e essa vigilância foi até 2004! Esses caras monitoravam a luta dos camponeses com relação às suas reparações. 


\title{
CRISTINA BUARQUE DE HOLLANDA:
}

\author{
A luta por reparações na Comissão de Anistia?
}

\section{PAULO FONTELES FILHO:}

Sim. Os caras fazendo esse monitoramento e esse Eduardo, que por algum motivo rompeu com os caras, começou a se sentir ameaçado e foi para o programa de proteção. Mas rompeu também com o programa e está lá na região, ameaçando a gente. Esse picareta. Tudo documento do Estado: fichas fundiárias, arquivos fundiários. Procuramos salvaguardar a integridade desses e também de outros documentos. Por isso decidimos fazer o recolhimento desse material. E voltamos agora para avaliar esse material recolhido e nos deparamos com a informação de que o dono deste museu, o organizador desse museu, foi agente do CENIMAR desde 73. Era um agente da repressão política. Durante muitos anos estiveram expostas nesse espaço coisas que pertenceram à guerrilha do Araguaia, como também dos documentos do GETAT. Também havia documentos que tratam dessa presença militar na Amazônia particularmente intencionada para a questão da luta e pela disputa da terra nessa região. Através dessa diligência nós vamos ter conhecimento de parte do que faziam os agentes da repressão, introduzidos aqui a partir do Projeto Rondon, na década de setenta. Quem fez esse documentário [referência ao documentário que exibe na tela do computador, Araguaia, Campo Sagrado] foi o Evandro [Medeiros], professor da UNIFESP. Ele trata dessa luta camponesa que se desenvolveu em toda a região do baixo Araguaia. Quando nós encontramos o material do museu, localizamos ali muita coisa relacionada à atuação da CPT, dos padres [franceses] Aristides [Camio] e Francisco [Goriou] ${ }^{v}$, do advogado Paulo Fonteles, do processo todo aqui desse conflito. Para nós foi surpreendente a descoberta dessa informação, quer dizer, de uma figura que ocupava um espaço social razoavelmente respeitado dentro da região de São Geraldo, em função de montar um acervo, mas que, na verdade, tinha montado uma fachada para ações de vigilância, monitoramento e espionagem próprias daquele período repressivo. Esse tipo de prática não se encerrou com a redemocratização do Brasil, em 1985. Essas medidas persistem até a década de 2000. Também me admira ter encontrado documentos relativos à luta que os camponeses fazem nessa região já há alguns anos. Uma luta que tem sido vitoriosa, uma luta que gerou a Associação de Capturados da Guerrilha do Araguaia e o monitoramento [mais recente] sobre esse processo, procurando naturalmente criar problemas ou impedimentos para a luta que fazem os camponeses por justiça, reconhecimento e reparação.

Então isso foi um episódio muito importante da Comissão da Verdade. Uma questão que nós já suspeitávamos e que ficou muito clara é que esse processo de vigilância não se encerrou na década de oitenta. Sabes que tem gente que nos diz, Cristina, que até 2002 havia gente do Exército que fazia incursões para encontrar combatentes perguntando a esses mateiros se tinha gente procurando coisa na região. Essa é uma estrutura que está viva. E tem outros episódios que revelam isso também. Por exemplo, aqui em Belém mesmo, no início da década de 2000, houve a localização de algumas ossadas no Forte do Castelo [região histórica da cidade]. Aqui em Belém, havia a $5^{a}$. Companhia de Guarda do Exército. E quando houve a obra de requalificação do Forte [onde esteve sediada a Companhia do Exército], em 2001, os operários da construção civil encontraram ossadas. Rapidamente foi feita uma operação que retirou esse material, e que foi liderada pelo pessoal da ABIN [Agência Brasileira de Inteligência]. [Estiveram envolvidos nessa operação] particularmente duas figuras que atualmente são da ABIN que foram do DOI-CODI e estiveram no Araguaia na década de setenta: Magno José Borges e Armando Souza Dias. Eu tenho participado desse processo desde [há muito tempo], denunciando essas coisas. 


\section{CRISTINA BUARQUE DE HOLLANDA:}

Paulo, você tem falado aqui em verdade, memória e justiça. Você poderia comentar essas três ideias? O que você entende por elas?

\section{PAULO FONTELES FILHO:}

Verdade é decisiva. Nós precisamos descobrir tudo. Quem foi, quando foi, por que foi. A verdade nos interessa, do modo que for. Isso para nós é fundamental. Não a fantasia que se faz da verdade. Descobrir, localizar e revelar ao país o que houve na Amazônia. E aqui a situação é gritante. Uma das situações que temos investigado no âmbito da Comissão é, por exemplo, o problema das multinacionais que aqui atuaram. Há um episódio desses que se liga à Volkswagen no Brasil; ela promoveu o maior incêndio a céu aberto no país que a humanidade já registrou, em 1976, numa fazenda chamada Vale do Rio Cristalino, em Conceição do Araguaia. Sabemos disso porque um satélite americano da Nasa [Agência Especial Norte-Americana] fazia um monitoramento climático da Terra e revelou esse episódio. Estamos trabalhando para revelar esse episódio todo e explicar o que foi isso, exatamente, para no futuro ser possível fazer a denúncia nos foros internacionais.

O problema da memória é decisivo. Um povo sem memória não é povo, é bando. A luta pela memória é fundamental para nós. Nós achamos que essa luta é tão importante que nós criamos esse Instituto e criamos o nosso portal, em que temos a parte de educação pela memória. Aqui existe mais de um milhão de páginas em acervo digital. O [arquivo primário do] Brasil Nunca Mais, a questão da luta pela terra, o centro virtual indígena e uma coleção de jornais paraenses. Meu pai completa trinta anos de assassinado. Uma das linhas em que nós temos atuado é a digitalização de setenta mil páginas que meu pai deixou de acervo. $\mathrm{A}$ memória tem um aspecto da cidadania e do combate. Quando o movimento pela memória, verdade e justiça afirma que...

\section{CRISTINA BUARQUE DE HOLLANDA:}

"Nunca mais se esqueça para que nunca mais aconteça"?

\section{PAULO FONTELES FILHO:}

"Para que nunca mais aconteça" é uma verdade, no sentido da não repetição.

\section{CRISTINA BUARQUE DE HOLLANDA:}

A memória tem a função de garantir uma não repetição?

\section{PAULO FONTELES FILHO:}

Tem essa função. E assegurar que as novas gerações saibam o que houve no país. A ditadura acabou há trinta anos e boa parte do nosso povo tem menos idade que isso. Eles não têm a memória disso. É preciso falar a essas gerações o que foi a repressão política. Os escrachos foram uma experiência muito interessante porque utilizou-se de movimentos de juventude para fazer os escrachos. Eles denunciaram o que foi e o que fizeram. E a justiça é tudo. Onde não impera a justiça há a barbárie! A impunidade. O Estado brasileiro tem uma dívida. Nos últimos vinte anos foram assassinadas mais de vinte mil pessoas, na luta pela terra, que é exatamente uma herança deixada pela repressão. A escola da pistolagem, o trabalho escravo, tudo isso é o recorte da Amazônia nos últimos cinquenta anos. O Judiciário paraense, nesse período todo, não conseguiu julgar quatro por cento dos casos. Noventa e seis por cento das mortes no Pará estão impunes, nos últimos vinte anos. Imagina a revolta e a humilhação que a gente sente. Imagina a sensação com a qual eu e meus irmãos acordamos todos os dias, revoltados?! Porque sabemos que nosso pai foi assassinado por 
essa estrutura, que permitiu a escola de pistolagem, com o assassinato de lideranças políticas, da reforma agrária, dos sem-terra e dos posseiros, dos advogados, religiosos, de parlamentares. $E$ até hoje não vimos a justiça e isso é uma humilhação permanente, que nos faz lutar constantemente, que nos incentiva a criar dispositivos como a Comissão da Verdade para que possamos gerar um país mais generoso com seus filhos e com menos orfandade. Meu pai foi morto por quem? Quem intermediou o assassinato do meu pai? Foi um cara que veio da operação Bandeirantes, que foi assessor do Maluf em São Paulo na década de setenta e que veio para a Amazônia para organizar as milícias do grande latifúndio. Foi essa turma e nós conseguimos julgá-lo. Mas os mandantes estão impunes como na imensa maioria dos casos. Não é simples. A luta pela memória, pela verdade e pela justiça é luta pelas bases civilizatórias da humanidade.

\section{CRISTINA BUARQUE DE HOLLANDA:}

Então justiça tem a ver com a resolução dessa situação de impunidade?

\section{PAULO FONTELES FILHO:}

Exatamente.

\section{CRISTINA BUARQUE DE HOLLANDA:}

E o desvelamento da verdade, de que você falava, também seria uma forma de justiça?

\section{PAULO FONTELES FILHO:}

Acho que sim. A justiça nem sempre está nos salões de mármore e entre os homens de toga. Ela se faz presente quando se denuncia um opressor. Os violentos são como baratas, têm medo da justiça. A forma imediata de justiça, aquilo que está ao nosso alcance, é fazer a denúncia e revelar a verdade. Não sei se você conhece essa história que também descobrimos. Não adianta pensar: "ah, a ditadura queimou tudo!" Queimou nada! Existem mais de quinze mil páginas digitalizadas no Arquivo Nacional, na Biblioteca Nacional. Agora, nós temos que estudar! Temos que ler! $\mathrm{E}$ foi isso que aconteceu em julho do ano passado. Lendo os materiais sobre os problemas [ocorridos na região] descobrimos um documento do Bradesco. Nós encontramos uma troca de correspondência entre o Ministro do Interior, Flavio Rangel, e o então chefe do Serviço Nacional de Informação, João Batista Figueiredo, 1974. E o Figueiredo denunciando ao Ministro do Interior que o Bradesco tinha matado SESSENTA camponeses numa queimada! Tinha levado um pessoal para o centro de uma terra, queimou em volta e sessenta morreram!

\section{CRISTINA BUARQUE DE HOLLANDA:}

Que loucura!

\section{PAULO FONTELES FILHO:}

Loucura. Está aqui. Nós publicamos. Eu e Marcelo Zenic escrevemos juntos vi.

\section{CRISTINA BUARQUE DE HOLLANDA:}

Era uma terra de propriedade do Bradesco?

\section{PAULO FONTELES FILHO:}

Era a fazenda do grupo deles. A fazenda Bradesco. Foi esse documento aquivii [aponta para a tela do computador]. Essa é a assinatura do Figueiredo.

\section{CRISTINA BUARQUE DE HOLLANDA:}

Impressionante! 


\section{PAULO FONTELES FILHO:}

O problema da verdade é também um problema de um esforço intelectual e humano de ler [e investigar] todo esse material que está disponível. Neste nosso portal temos um milhão de páginas. Quantas eu li? Se foi dez mil, foi muito! E o restante disso? Quer dizer, tem muita coisa [a ser investigada] A verdade também é um esforço que deve ser realizado pela universidade, pela militância.

\section{CRISTINA BUARQUE DE HOLLANDA:}

Por equipes de pesquisa.

\section{PAULO FONTELES FILHO:}

Exatamente. Esse material, no geral, tem que estar nas universidades para que nós encontremos outras coisas, tal como nós encontramos esse documento. Você conhecia essa história?

\section{CRISTINA BUARQUE DE HOLLANDA:}

Não! Não fazia a menor ideia dessa história.

\section{PAULO FONTELES FILHO:}

Há muito material. Essa coisa que se diz que a repressão não batia foto. Mentira! Eles documentavam tudo. Quando eu comecei esse trabalho no Araguaia, em 99, eu decidi criar esse blog [http://PAULO FONTELES FILHOfontelesfilho.blogspot.com/]. Ele teve mais de um milhão de visualizações, o que é muito para o tema de memória, verdade e justiça.

Encontramos muitas fotografias sobre o período. Eu tenho a convicção do seguinte: que a gente ainda vai demorar muitos anos para pode revelar tudo, sabe? Eu tenho essa convicção. Eles fizeram imagens e esse tipo de coisa. E estão todas por aí, como por exemplo, as crianças sequestradas no Araguaia. Nós precisamos ter uma força-tarefa que trate e dê conta dessa tarefa de função democrática. Não é simples.

\section{CRISTINA BUARQUE DE HOLLANDA:}

Paulo, você poderia falar um pouco sobre direitos humanos. O que você entende por esse conceito?

\section{PAULO FONTELES FILHO:}

Direitos humanos é uma moral civilizatória, é compreender a humanidade como uma grande família. E as bases disso estão lá na Carta da Virgínia, no final do século XVII. Depois, passando pela Revolução Francesa e que depois vai se afirmar no século XX depois dos horrores da II Grande Guerra Mundial. Na minha opinião, direitos humanos constituem um meio de vida. Uma forma de fazer o bom combate, de denunciar os poderosos e a impunidade, no sentido da luta por uma sociedade igualitária e mais justa. Uma sociedade do futuro. Eu os vejo como muito importantes.

\section{CRISTINA BUARQUE DE HOLLANDA:}

O ativismo em direitos humanos tem muito a ver com a denúncia das violações de direitos humanos.

\section{PAULO FONTELES FILHO:}

Eles [os direitos humanos] também dão maior visibilidade pública aos poderosos e ao modo como eles se organizam como hienas raivosas, que precisam ser enfrentadas. Eu sou militante de direitos humanos, mas não sou pacifista. Acho que são duas coisas diferentes. É 
preciso enfrentar as arbitrariedades, denunciar ao que eles submeteram a região e o povo da Amazônia, os camponeses e aqueles que para cá vieram. Essas estruturas não desapareceram. Muito pelo contrário, o modus operandi permanece o mesmo. Não à toa o estado do Pará permanece o campeão de trabalho escravo no país. O último censo do Ministério do Trabalho e Emprego diz que trinta por cento do trabalho escravo no Brasil ocorre no Pará. Por que ocorre isso? Qual a história disso? A história disso daí é a penetração econômica que a repressão abriu. Essa luta dos direitos humanos é importante e fundamental e precisamos participar dela com conviç̧ão. Olha, aqui temos uma videoteca com curtas censurados com realizadores paraenses, entre eles o Evandro, que tem um curta muito interessante chamado Araguaia, campo sagrado. É um filme de 2010. Um dos melhores filmes já produzidos sobre as guerrilhas. Temos 175 filmes que é a mostra Brasil: Nunca mais. Isso aqui também é luta pela memória. A gente tem sido muito procurado por conta do portal e devido à educação pela memória. No geral é muito complicado acessar um pesquisador e um documento. Então, precisamos disponibilizar esse material. Eu me relaciono com o mundo acadêmico e predomina muito o pensamento: "eu encontrei o material, ele é MEU, ando com ele debaixo do braço para ninguém ver!" Nós precisamos disponibilizar a documentação que nós encontramos para que qualquer pessoa possa acessar: o estudante secundarista, o estudante de graduação, qualquer cidadão. Isso aqui também é luta pela justiça, luta pela verdade e luta pela memória.

\section{CRISTINA BUARQUE DE HOLLANDA:}

Paulo, na descrição do seu blog, você diz que o Instituto não é partidário e que está envolvido com uma luta política pelos direitos humanos. Eu queria que você comentasse sobre os direitos humanos como luta política. Outros ativistas que evocam os direitos humanos querem justamente esvaziá-los de feição política e caracterizá-los como imparciais.

\section{PAULO FONTELES FILHO:}

Isso não existe! É estúpido demais! Primeiro que a negação da luta política é a antessala do fascismo. Quem é que nega a luta política? Eu já vi coisas que me deixaram escandalizado. Exemplo: o dia das mulheres. O presidente da Comissão de Direitos Humanos vai para o ato e é hostilizado no ato. E ele não é uma pessoa de direita, um pastor de igreja evangélica, não. Uma pessoa que desde a década de setenta tem ligação com a luta dos trabalhadores, do povo, das mulheres, de redemocratização. E ele foi hostilizado! A bandeira dos direitos humanos será consagrada nesses marcos da despolitização?! Da negação da política?! Porque na história, sobretudo, os direitos humanos aparecem como uma luta política. O que foi a Carta da Virgínia?! De 1776? Foi uma manifestação autonomista, de luta contra os ditames dos ingleses. A luta dos direitos humanos aparece nessa perspectiva. Outro exemplo é o processo que a revolução francesa coloca. A revolução industrial também. Essa questão dos direitos civis e políticos, mas também do direito ao trabalho, à autodeterminação dos povos, direito ao desenvolvimento. São todas questões políticas. Eu tenho a impressão que boa parte da militância em direitos humanos no Brasil são contaminados por posições muito estranhas, posições multiculturais. Como se quisesse pegar o discurso branco de Harvard e aplicar sobre o Brasil. O próprio discurso sobre minorias.

\section{CRISTINA BUARQUE DE HOLLANDA:}

Você pode falar mais sobre isso?

\section{PAULO FONTELES FILHO:}

Negro é uma coisa, mulheres, juventude, outra. Existe uma fragmentação demasiada dessa luta. Eu fico meio abobalhado com certas coisas. Como foi o episódio daquela moça branca, 
com câncer, que usou um turbante. A confusão que deu em relação a isso. Muita despolitização e negação da política.

\section{CRISTINA BUARQUE DE HOLLANDA:}

Você associa o processo que você chama de luta multicultural nos direitos humanos a esse fenômeno de despolitização dos direitos humanos?

\section{PAULO FONTELES FILHO:}

Exatamente. De fragmentação. Por exemplo, qual é a maior bandeira dos direitos humanos no Brasil na atualidade? É a democracia. Não é outra coisa. É o restabelecimento da vida democrática do país, que atinge um nível de muita importância e de urgência. Isso carrega outros temas, como a questão dos negros, das mulheres, das ditas minorias. Como é que se diz que negro é minoria no Brasil?! Não é! Mulher é minoria no Brasil? Não é! Ao longo desses últimos trinta anos foi calcada uma visão de uma sociologia branca americana. Porque lá é tudo fatiado mesmo. Branco fica de um lado, hispânico fica de outro. Ninguém se mistura! Aqui no Brasil, não! O Brasil é um país de muita miscigenação, que não pode ser confundida com democracia racial. Porque o Brasil é um país em que a pobreza e a miséria têm raça e têm gênero. São as mulheres negras as mais pobres e mais violadas. Nós não podemos enfrentar essa luta com essa despolitização toda. É preciso entender que os direitos humanos são uma ferramenta do progresso e da transformação, da luta de classes. É uma afirmação para isso. A quem interessa a luta dos direitos humanos é a transformação da sociedade por uma superior. Primeiro que somos um instituto apartidário. Aqui não é uma corrente de transmissão ao partido ao qual sou filiado. Mas ao mesmo tempo que é apartidária é uma instituição politizada. Mas isso não significa criminalizar nem hostilizar os partidos políticos, como estão fazendo com o PT hoje. A gente precisa problematizar isso: colocar partidos na criminalidade no Brasil é tradição da direita, como fez com o Partido Comunista e como vêm tentando fazer com o PT hoje. Os direitos humanos são uma baioneta importante para enfrentar os poderosos, os Bolsonaros da vida, os fascistas. Nós atuamos na luta pelos direitos humanos nessa perspectiva: socialista e de que temos um lado. "Não tenho lado." Quem diz que não tem lado vai se abraçar com o opressor! Tu leste o último relatório que saiu da Anistia Internacional?

\section{CRISTINA BUARQUE DE HOLLANDA:}

Não.

\section{PAULO FONTELES FILHO:}

O relatório da Anistia Internacional indica que se deterioram os direitos no país com o golpe, a escalada de violência a que assistimos. Nós vamos lutar pelo Fora Temer, pelas Diretas Já. Eu e Angelina, minha companheira, escrevemos um pouco sobre o que relatório [da Anistia Internacional] diz sobre o Brasil. Lemos o relatório e publicamos nossa opinião sobre isso. Como olhar para isso de forma despolitizada?! Até nos metemos numa confusão por causa disso, porque ontem a Ministra de Direitos Humanos esteve aqui em Belém, com um deputado desse campo deles, e queria que a gente fosse lá. Eu ia fazer o quê lá?! Vou ficar chancelando uma Ministra que é um fantoche?! Que apesar de ser uma mulher negra está se prestando a isso, no meio desse Ministério de homens brancos, gordos e ricos. Não. Nossa luta é democrática. O centro da luta por direitos humanos no país tem esse caráter democrático. O problema [do ativismo em direitos humanos hoje no Brasil] é a fragmentação. Porque cada um cuida do seu quadrado e quem é que cuida do geral?! Os direitos humanos são indissociáveis. O problema do negro na periferia, o problema da mulher, o problema da violência policial, o problema dos camponeses que são atingidos pelo 
latifúndio, são os indígenas atingidos pelo agronegócio... Precisamos olhar para isso como um todo. Esse é um tema que nos interessa, mas no geral existe muito preconceito.

\section{CRISTINA BUARQUE DE HOLLANDA:}

Preconceito com?

\section{PAULO FONTELES FILHO:}

Com uma visão partidarizada dos direitos humanos. Te dou um exemplo. No filme do Evandro em que participei, chamado Araguaia, campo sagrado, se fala de homens-soldados, mas não glorificando ninguém porque foi o que aconteceu. Aí fomos apresentar o filme em São Paulo e recebemos muita crítica. Pessoas dizendo: "ah, não vou assistir a um filme em que passa um militar..." O homem era um SOLDADO, não era um Curió! (- Riso) O cara está nos ajudando a compreender tudo isso que ocorreu com o Brasil! Tem muita gente nossa que tem o AI-5 na cabeça. Então é muito difícil se relacionar com certos familiares [de mortos e desaparecidos políticos], por exemplo. Quem são os mateiros? Que eram camponeses que ajudavam o Exército a encontrar os guerrilheiros? Esses caras foram todos torturados, Cristina! O cara com uma 765 na cabeça, com a mulher e os filhos sob ameaça de estupro?! A pessoa vai colaborar, evidentemente. No documentário sobre a guerrilha, eu conheci mais de cem mateiros. E só conheci uma pessoa que afirmou que foi voluntariamente porque gostava do Exército e era anticomunista. O restante todo passou pela "taca". "Taca" é o espancamento. Daí você não querer ouvir essa voz, não julgá-la vítima?! Você classificá-la como se classifica o Ulstra, o Curió, o Figueiredo?! É diferente. Eu escrevi um artigo sobre isso chamado "Sobre lobos e meninos" [disponível em:

https://vermelho.org.br/coluna/sobre-lobos-e-meninos/]. Uma das coisas que mais me impressionou nesse processo todo foi ouvindo esses ex-soldados - que colocaram tudo em pratos limpos, mesmo! Disseram que houve operação de limpeza e que participaram dela, que o Luís Figueiredo, então chefe da oitava região em Belém e irmão do João Batista Figueiredo, coordenou a primeira campanha de operação de limpeza. Um desses mesmos soldados, um soldado que foi estuprado por um coronel, me disse o seguinte: ele cortava o cabelo do oficial e, ao fim do corte, o coronel botava uma 765 sobre sua cabeça para estuprar o rapaz de 19, 20 anos de idade. E era um hábito do oficial fazer isso com o jovem. Ouvi uma história que me deixou uns três dias sem dormir, de um soldado chamado Euclides, cuja família toda é de Tucuruí, no Pará. Uma família socialmente ativa: o pai militava no bairro, um tio era vereador e outro presidente de uma organização associativa. Todos foram presos. E esse soldado Euclides foi levado por dez dias a ouvir o pai sob sessões de tortura. Ficava escutando o suplício do pai. Quando eu escutei essa história, eu quis morrer, porque a brutalidade humana não pode ser tão perversa. $\mathrm{E}$ os comandantes faziam isso conscientemente, ou seja, sabendo que era o pai dele. E eu vou chamar esse soldado que levava o pai para a sessão de tortura de bandido?! Eu não posso. Ele era apaixonado pelo pai e depois disso só se viram uma vez. Nunca se reconciliaram, nunca se abraçaram. É uma história que causa perplexidade na gente. Eu não posso ter uma visão imparcial, de quem não sabe o que é isso. Eu sei o que é a tortura. Existe uma memória da carne. Nós temos de ver tudo isso de uma com humanidade. Nós temos de ter essa atitude. Teve muita gente que foi apenas como mais uma peça na engrenagem.

\section{CRISTINA BUARQUE DE HOLLANDA:}

Paulo, a partir do que você está me dizendo, eu poderia entender, a depender das circunstâncias, a luta por direitos humanos pode envolver uma cooperação com governos que estejam comprometidos com causas de direitos humanos. Você, por exemplo, não foi se encontrar com uma Ministra de Direitos Humanos do governo Temer, mas numa outra 
circunstância, com outra Ministra, talvez você não se negasse a cooperar com o governo. Estou certa?

\section{PAULO FONTELES FILHO:}

Claro. O problema é que o governo subjugou a democracia. Por isso que não nos cabe [cooperar com esse governo] também. No Brasil, os direitos estão sendo todos destruídos e destroçados. Dos trabalhadores e do povo como um todo.

[A conversa é interrompida pela chegada de uma equipe da TV Record que Paulo recebia no Instituto para uma reportagem sobre Direitos Humanos no Pará. Não tive a oportunidade de fechar a conversa]

(Recebido para publicação em setembro de 2019)

(Reapresentado em outubro de 2019)

(Aprovado para publicação em dezembro de 2019)

\section{Cite esta entrevista}

FILHO, Paulo, 2019. Entrevista com Paulo Fonteles Filho, conduzida por Cristina Buarque de Hollanda. Revista Estudos Políticos: a publicação semestral do Laboratório de Estudos Hum(e)anos (UFF).Rio de Janeiro, Vol.10 |N.2, pp. 160-178, dezembro de 2019.

\section{Notas}

1. Paulo Fonteles foi deputado, sindicalista e advogado de trabalhadores rurais no Pará assassinado por pistoleiros depois de enfrentar latifundiários da região. Fonte: Memorial da democracia. Disponível em: http://memorialdademocracia.com.br/card/pistoleirosmatam-advogado-no-para. Acesso em 11 de maio de 2020.

2. O Grupo de Trabalho Tocantins foi criado pelo Ministério da Defesa, por meio da Portaria no. $567 / M D$, de 29 de abril de 2009, com equipe composta por integrantes do Exército e representantes da sociedade civil para ida a campo. O objetivo era cumprir decisão judicial de ação proposta em 1982 por familiares de 22 desaparecidos na guerrilha do Araguaia.

3. Com a condenação do Brasil na Corte Interamericana de Direitos Humanos pelo caso Gomes Lund e outros [Guerrilha do Araguaia], no final de 2010, a Portaria Interministerial no. 1 , de 5 de maio de 2011, ampliou e reestruturou o então Grupo de Trabalho Tocantins (criado em 2009, pela Portaria no. 567/MD, de 29 de abril de 2009), que passou a chamar-se Grupo de 
Trabalho Araguaia.

4. Referência à inclusão de camponeses entre o grupo de beneficiados com indenizações da Comissão de Anistia.

5. Em janeiro de 1981, Aristides Camio e Francisco Goriou, ambos ligados às Comunidades Eclesiais de Base (CEBs), foram presos pela Polícia Federal acusados de incitar posseiros de São Geraldo, região sul do Pará, à violência. Foram enquadrados na Lei de Segurança Nacional, condenados e presos por dois anos.

6. FILHO, Paulo Fonteles; ZELIC, Marcelo. "Amazônia: Figueiredo e a matança de 60 trabalhadores rurais". Disponível em: http://institutopaulofonteles.org.br/2016/07/12/amazo nia-bradesco-a-denuncia-de-figueiredo-e-a-matancade-60-trabalhadores-rurais/ Acesso: 11 de maio de 2020.

7. Trata-se de correspondência confidencial de 5 de junho de 1974 emitida pelo então chefe do Serviço Nacional de Informação (SNI) e membro do Conselho de Segurança Nacional, General João Batista Figueiredo, notificando o Ministro do Interior, Maurício Rangel Reis, sobre "problemas de terras em Conceição do Araguaia no Pará". O conteúdo do documento é detalhado no artigo citado na nota 6. 